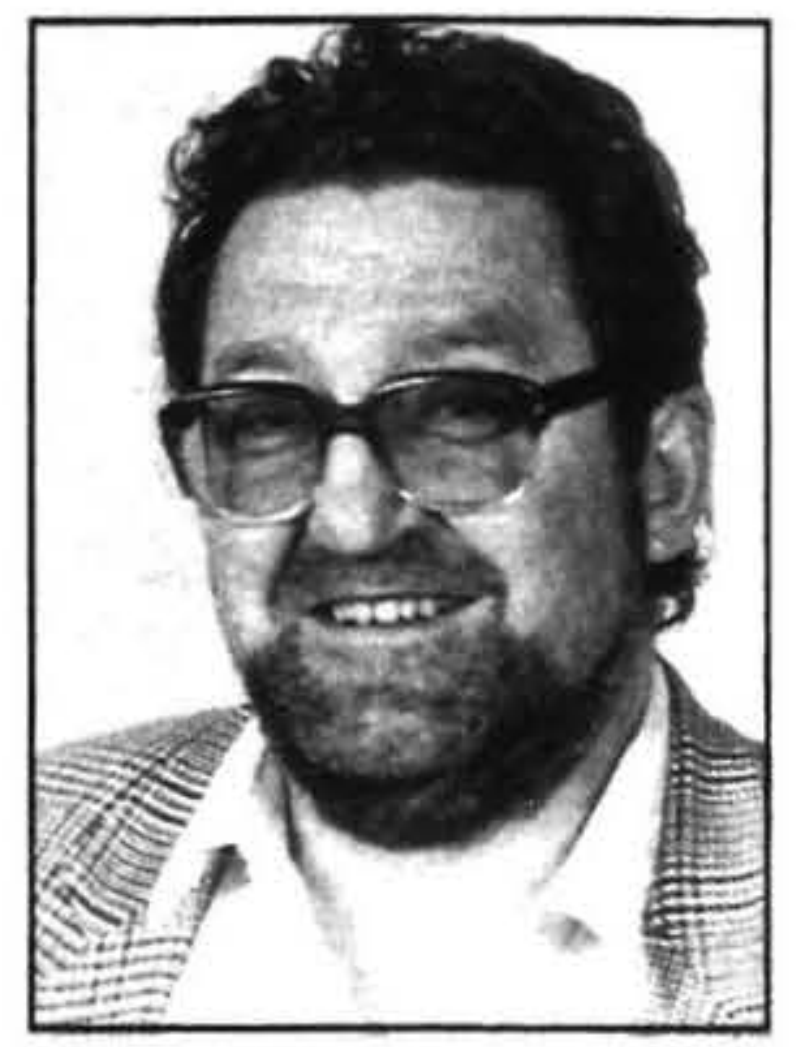

\title{
BRENDAN THOMPSON'S NEW ZEALAND WORKFORCE SERIES
}

Brian Easton

Economic And Social Trust On New Zealand

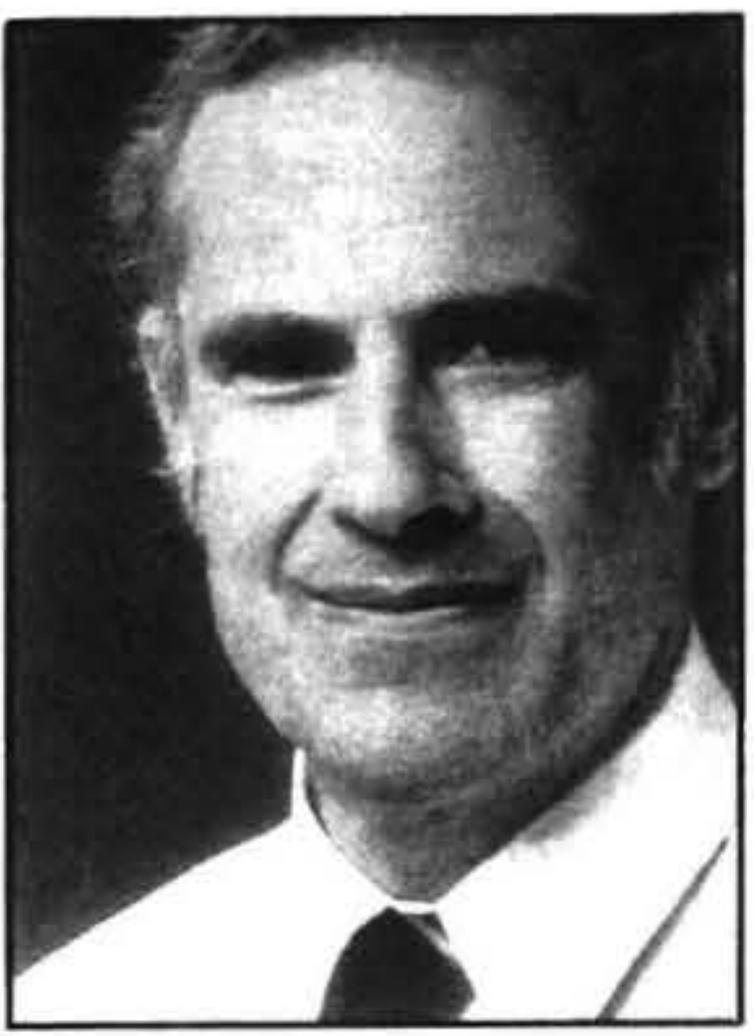

Brendan Thompson

\begin{abstract}
Economic historian Brendan Thompson died earlier this year. His life's scholarship involved calculating a series of the New Zealand workforce. The paper reports on this work, and provides some of the aggregate data which Brendan had produced.

Brendan James George Thompson, senior lecture in economic history at the University of Waikato, died in January 1996 , at the age of 52 . He is affectionately remembered by his family, his friends, and his colleagues and students for his enthusiasm and commitment, his loyalty and integrity, to individuals, to his discipline, to the academy, and to the wider public. But for even longer he will be remembered by the scholarly community for his life's work of the construction of a long run series of the New Zealand labour force. This paper provides an overview of his painstaking work.

so far. Three previous researchers ${ }^{2}$ have already attempted it and given up, defeated by the complexities. I have progressed further than any of my predecessors and am convinced that all that is required are time and, above all, persistence. Much more tedious, detailed work needs to be done, the major stumbling block being the interwar years. The figures for that period need to be revised because the censuses on which they are based are so inaccurate. They can be improved using alternative sources.
\end{abstract}

Following his completion of a Masters degree at the University of Canterbury, Brendan was a student at the University of Pennsylvania from 1970 to 1972 , where he graduated at the top of the masters class in economic history in 1971 and was awarded a Pennsylvania Scholarship. He registered for a doctorate on the topic of the industrial structure of the New Zealand work force. He wanted to create data series which would be internationally comparable, and originally intended to do some international comparisons, for Brendan was very interested in cross national comparisons. Indeed he did some such comparisons in the 1990 s, but it was the task of compiling the data upon which he most worked. A brief record of his life appears in appendix I, while his publications list in Appendix II. He planned a monograph out of this work, which he described in a curriculum vitae prepared in 1994 as follows:

\section{Industrial Structure of the New Zealand Work Force}

I also plan to continue the years of work that I have done on the industrial structure of the New Zealand work force. My chapter in the ESCAP monograph on New Zealand is a preliminary study. To be really useful the subdivisions need to be finer. The potential contribution of this work to General History is enormous. ...

The final series will also be used to provide better historical GDP estimates than we have at present. Another series that could be derived from it could be used to help illuminate regional variations within New Zealand history.

This project has involved an immense amount of work
Thus Brendan left only a partially completed manuscript of Industrial Structure in New Zealand (hereafter ISNZ). A brief summary of its contents is provided in Appendix III. Yet ironically, the work up to 1921 was close to completion. Perhaps by the time Brendan realized that it could be completed the final illness had exhausted the strength he had. But perhaps the perfectionist in him meant that he always wanted to do a little more work - "polishing" he liked to call it.

There is a rather special feature of the Thompson work force series compared to most of the quantitative historical series academics have constructed. Usually series (I include my own), are constructed for a particular purpose, which determines the effort that is put into them. If there was time the quality of the series could have been improved, but there never is, for there is always another task to be tackled, another series needed for it. Brendan's series was constructed with a more general purpose in mind - not for a particular task - but as a series in its own right which would be used by any scholar knowing that it was the very best available.

\section{The statistical series}

Nineteen of the 22 main tables which Brendan prepared have thus far been found. (Appendix IV) They are for the five years of official surveys between 1839 and 1851 , and for each census year from 1858 to 1981 . They are presented in three broad sections, reflecting more increasingly sophisticated definitions of industrial structures: 1839 to 1871 ; 1871 to $1936 ; 1936$ to 1981 . 
Brendan uses the expression "work force" rather than the more conventional "labour force", that is those actively engaged in paid work (including relative assisting) or unemployed and actively seeking work. However Chapter 2 of ISNZ makes it quite clear that the intention is that the two terms be interchangeable, as far as is possible given the original data sources. ${ }^{3}$ ISNZ uses a formal definition from the 1966 Population Census - the definition used since 1936. It was typical of his meticulous interest in the detail of the series (together with his interest in the issue of women's paid and unpaid work), that he put a lot of effort developing a measure of the number of farmer's wives who were unpaid "relative assisting".

Brendan concluded that "it is possible to obtain an estimate of the labour force reasonably consistent with that of 1966 by adjusting the published figures for censuses from 1916 to 1936 [although a]bsolute consistency is not possible" (Chapter 2:11). More cautiously "[b]efore 1916 the estimates of the labour force are less likely to be consistent with the 1966 definition especially in the early years when one has to be content to make the best of available information. Despite their imperfections, they are likely to reflect the

Table 1. Brendan Thompson's New Zealand Work Force Series

\begin{tabular}{lllll}
\hline Year Male Female & Total Maori $\begin{array}{l}\text { \# of } \\
\text { sectors }\end{array}$
\end{tabular}

\begin{tabular}{rrrr} 
& \multicolumn{3}{c}{ non-Maori } \\
1839 & & & 448 \\
1843 & & & 5,141 \\
1845 & & & 5,523 \\
1848 & & & 7,436 \\
1851 & & & \\
1858 & & & 21,273 \\
1861 & & & 50,613 \\
1864 & & & 88,012 \\
1867 & & & 96,956 \\
1871 & & & 104,943 \\
1874 & 109,553 & 14,652 & 124,205 \\
1878 & 143,208 & 21,408 & 164,616 \\
1881 & 164,105 & 24,923 & 189,028 \\
1886 & 190,083 & 32,605 & 249,822 \\
1891 & 204,973 & 44,849 & 289,642 \\
1896 & 237,070 & 52,572 & 289,642 \\
1901 & 269,046 & 64,414 & 333,460 \\
1906 & 316,832 & 73,066 & 389,808 \\
1911 & 353,836 & 90,339 & 444,175 \\
1916 & 342,841 & 104,287 & 447,124 \\
1921 & 398,903 & 116,683 & 551,586
\end{tabular}

\section{5}

5

5

5

5

5

5

5

5

$5 \& 10$

10

11

11

11

$11^{*}$

$11^{*}$

$11^{*}$

$11 *$

$11^{*}$

$11^{*}$

$11^{*}$

Maori \& non-Maori

$1926 \quad 456,093 \quad 126,959 \quad 583,052$

\section{$1936 \quad 524,825$ \\ 147,916 \\ 666,406}

1945495,476

1951568,963

1956622,758

1961670,506

1966745,595

1971784,969

$167,263 \quad 659,528$

$171,533 \quad 735,421$

$194,094 \quad 812,673$

$224,857 \quad 891,781$

$280,444 \quad 1,019,253$

$333,866 \quad 1,105,027$

$1,272,000$

1976

adj 850,700

$395,300 \quad 1,246,000$

$1981846,300 \quad 437,100 \quad 1,283,400$

* Also available by Employment Status. major trends, even if they fail to do so precisely" (Chapter 2:12).

The data is available by industrial sector from 1839 , by gender from $1874,{ }^{4}$ and by employment status (including unemployment) from 1891. A major lacuna, which reflects the data sources, is that there are no Maori data before 1926. Only non-Maori is tabulated. (Brendan published papers on the Maori work force in 1978 and 1985.)

\section{The long run series}

As Appendices IV and V show, there are a multitude of tables, and hence of data available over the period. This is not the place to report all of it. Brendan's scholarly papers are currently in the possession of the family, with the intention of their being deposited in a suitable scholarly archive. ${ }^{5}$ Table 1 gives is the basic series of the Thompson Work Force estimates.

Rather than comment on the work force series, the next two sections illustrate its usefulness with a couple of examples.

\section{Output per worker 1861-1981}

Given GDP, output per worker can be calculated from the Thompson series. ${ }^{6}$ There are no direct estimates of GDP before 1917/18, but Keith Rankin has provided a real GNP series based on money multipliers ${ }^{7}$ Since this reflects only the monetized part of the economy, it may be compared with the non-Maori work force (i.e. assuming that in the nineteenth century the Maori were only a small part of the monetary economy).

In the interwar period there is a direct estimate of nominal GDP derived by Brent Lineham, ${ }^{8}$ and an official GDP data back to $1931 / 2$. However a price index has to be synthesized, to construct a real GDP series. ${ }^{9}$ This is compared with the total (Maori plus non-Maori) workforce.

The resulting series, linked together are shown in Figure 1. Because most years are omitted, because the New Zealand economy has a strong cycle, and because measurement errors abound, the result is only indicative trends. However they suggest that output per worker was relatively constant through the nineteenth century to the early 1930s, and has risen rapidly in comparison since (to 1981 anyway).

Since the key data series - the Rankin real GNP series, and the Easton GDP deflator series - have been synthesized with much less care than the Thompson work force series we might wonder whether they are subject to such high margins
$21,659 \quad 11^{*}$ $26,14211 \& 13 *$ $29,16513^{*}$ $31,67713 *$ $38,800 \quad 13 *$ $46,95313^{*}$ $56,89913 *$ $67,49713 *$ $82,98013 *$ $82,980 \quad 13 *$ $94,19513 *$ of error that the above graph is indicative rather than accurate. Nevertheless Brendan, a long time collector of long term series, would have enjoyed this series, happy to mull it over, wondering about its meaning.

\section{Industrial shares in the political economy of New Zealand}

The second illustration may seem indulgent, but Brendan 
was an enthusiast for the use of his material in some work I have been doing on the political economy of New Zealand. He wrote in his 1994 curriculum vitae:

Brian Easton's 1994 Hocken Lecture is but one example. ${ }^{10}$ As he will illustrate, this work can be used to provide the foundation for a major reinterpretation of New Zealand history. He argues that until the advent of refrigeration, New Zealand was primarily a quarry, depending for its prosperity on unsustainable industries such as gold mining, milling indigenous forests and kauri gum digging. This, he claims, produced in much of the country the sort of society portrayed by [Miles] Fairburn. The more sustainable economy produced by refrigeration produced a very different society which made different demands on politicians.

The lecture's broad thesis was that economic history should be a more integral part of historical studies in New Zealand, something with which Brendan enthusiastically concurred when I discussed the paper with him on a number of occasions. I illustrated my thesis by setting down an alternative account of New Zealand history, in which I argued that it could be envisaged as a set of political economies ways of organizing the economic activities of a nation competing within overall economy.

In particular I argued that the nineteenth century could be seen as three major political economies - I likened them to tectonic plates - vying for supremacy. The oldest was the Maori economy coming to terms with the external pressures caused by the arrival of the Europeans. The second was the Quarry which was involved immigrant activities dependent upon depletable resources which would eventually be exhausted. (Gold is the most obvious example, but whaling and sealing, other minerals, indigenous forestry, and kauri gum were all important at various times.) The third was the Settler Economy, characterized by the development of a sustainable mode of economic activity. My thesis is that these are not merely economic modes of activities, but they shaped New Zealand's society. The politics of the nineteenth century can be - and should be - interpreted in terms of the tensions between the various political economies.

My argument was largely (and for a statistician, strangely) qualitative. That was because there are no output series for most sectors before $1917 / 18$. However the Thompson work force series offers alternative way of quantifying the political economy of New Zealand, although because the data sources did not cover the Maori, the size and significance of the nineteenth century Maori political economy remains a mystery.

Figure 2 shows the industrial shares of the workforce in four categories from 1839 to $1981 .^{11}$ The first category is the soldiers who were here to operate in New Zealand. They disappear form the statistics by the end of the 1870 s, shifting to the 'other' category. If one wanted to do a finer analysis of their role, the more detailed Thompson tables can be used. At this point, I acknowledge that the Thompson series suggests my Hocken lecture underestimated the role of the military as an economic factor in the early settlement.

Next is the Quarry - mining, hunting fishing, and forestry (which was largely the clearing of indigenous clearing until the middle of the twentieth century). ${ }^{12}$ The third is farming, which includes both supply to the quarry as well as an activity in its own right for export and supply to the settlement. I was surprised that the decline of farming in occupational share begins as early as 1895 according to this series.) Manufacturing, on the other hand seems to peak about $1970,{ }^{13}$ while the share of other, primarily the service

\section{Figure 1. Output (GDP) per worker 1861-1981}

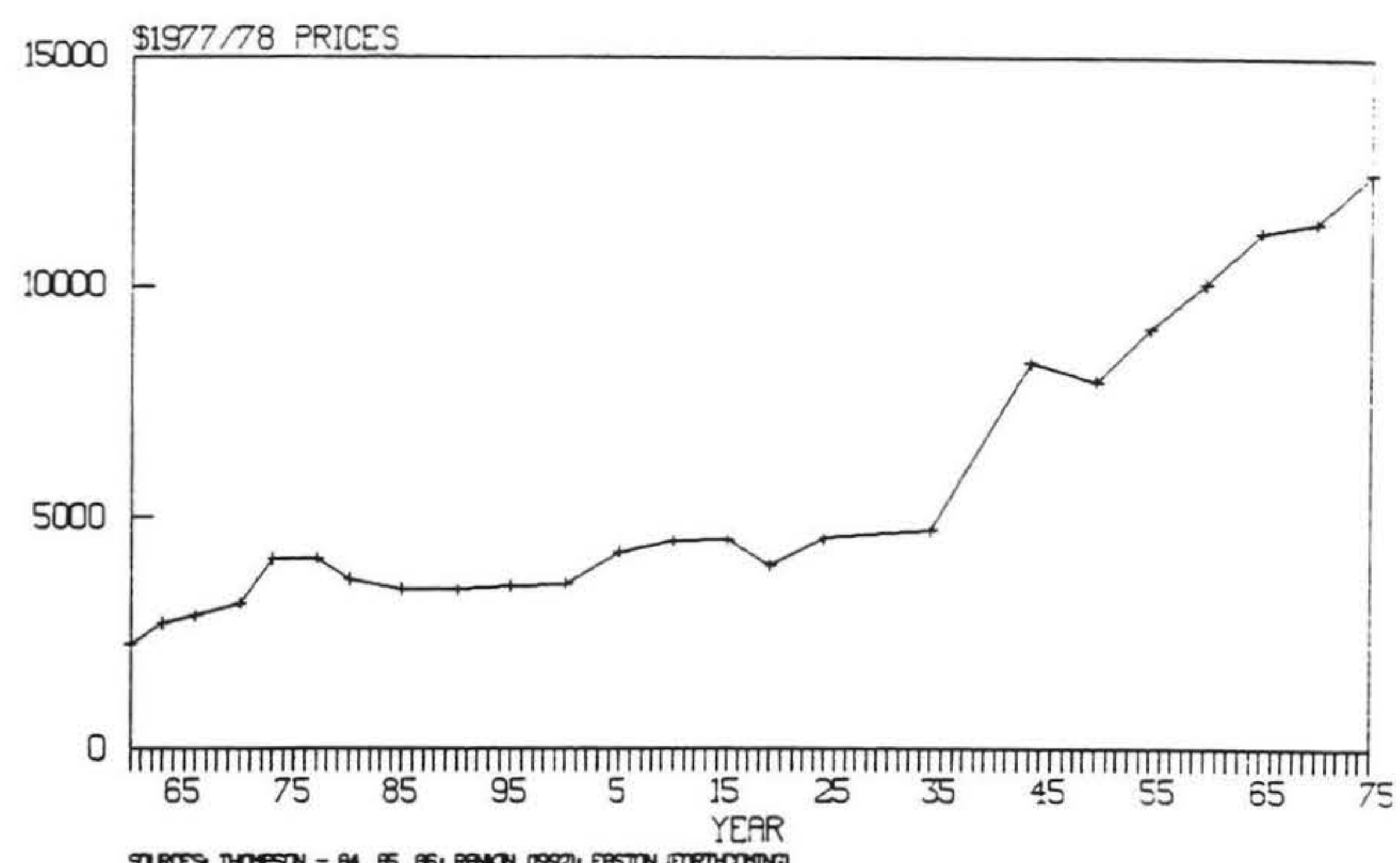

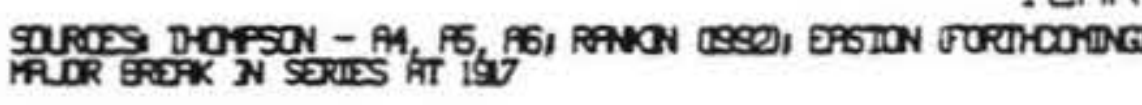


sector and which supplies the other three sectors (until recently, when tourism became an export activity in its own right) grows throughout the period.

The overall pattern was similar to that of other rich countries, as Brendan explored in some of his published papers. What we have here is a better account of the magnitude and timing of the trends. Moreover, while these figures are very aggregated, by going back to the working papers a more detailed account may be studied. For instance, Brendan combined mining in manufacturing because international comparisons require that, whereas I have separated the sector out because their political and social impacts are different.

The story the Hocken lecture told of the importance of the Quarry in the middle of the nineteenth century, and its diminution thereafter is evident enough in Figure 2. The real test of the data's usefulness is the extent to which I would change my thesis now having access to it. The answer is not merely that it confirms the broad argument, but it offers a number of refinements and extensions, both to the nineteenth century story and to the twentieth century one. The elaboration of this belongs to another venue. However, I do wish that I could have discussed the data and my interpretation of it with Brendan before I write it up.

\section{Conclusion}

Of course these are not the only uses of the Thompson series. Scholars of New Zealand's economic and social history will use them for many different purposes. It is an immensely valuable resource. Despite Brendan Thompson's many other important and valuable activities over his - alas - too short life, the Thompson series is his greatest contribution to scholarship and a monument to the scholar.

\section{Future research}

Undoubtedly Brendan would have wanted further "polishing" of his data base, and there is a need to update it, something which might wait for the release of the 1996 Population Census data. However his work force series provide a sound quantitative basis for demographers, economists, historians and sociologists - among others - concerned with the aggregate and structural change of New Zealand over the last 160 odd years, and is likely to lead to a stimulating debate on these issues.

There is a wider research project here. The historical series presented here are just one of a multitude quantifying New Zealand's economic and social history, which have been prepared over the years - some officially, some by academics such as Brendan. There is no readily accessible source

\section{Figure 2. Industrial sector shares (cumulative) 1839- 1981}

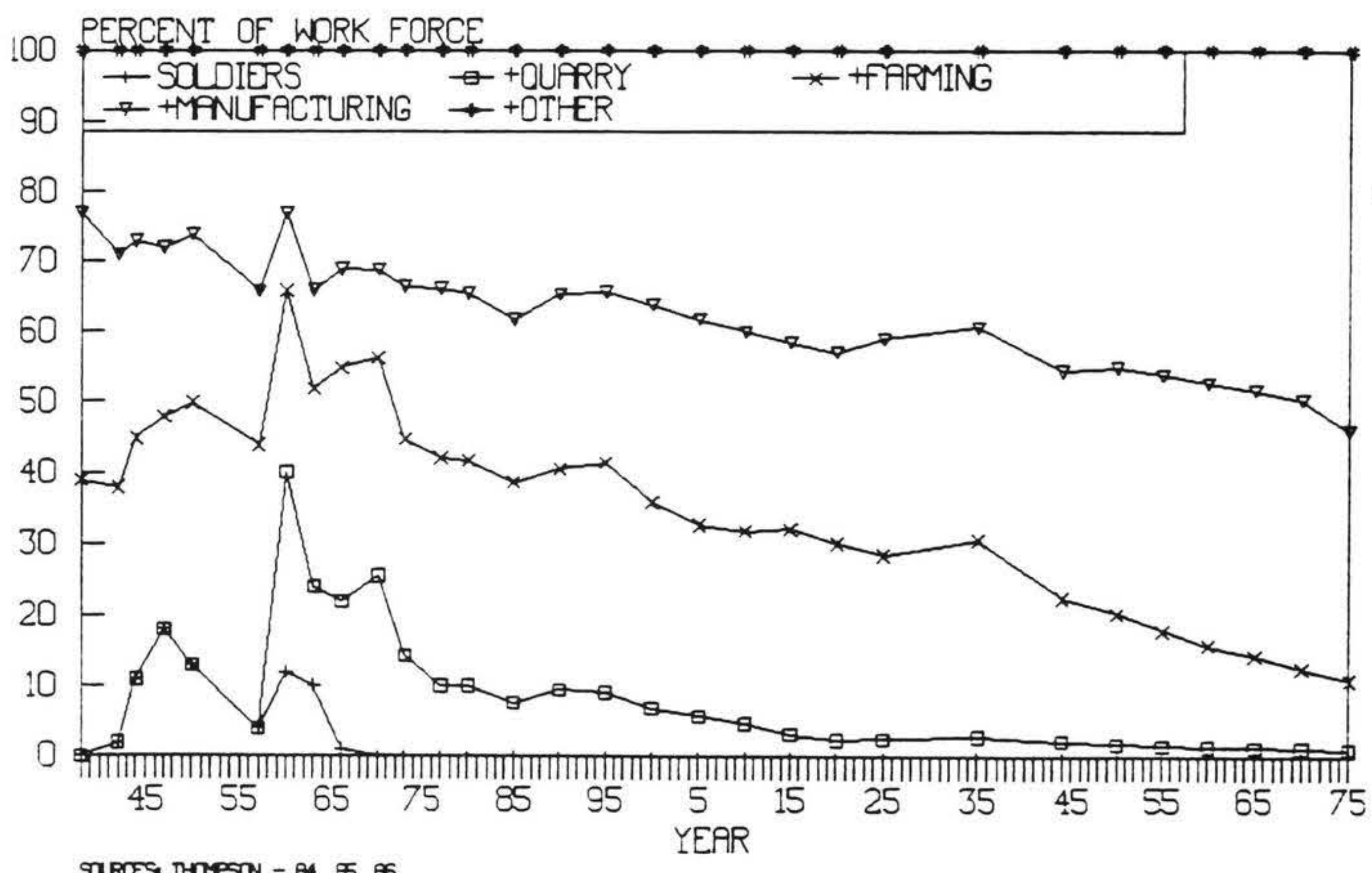

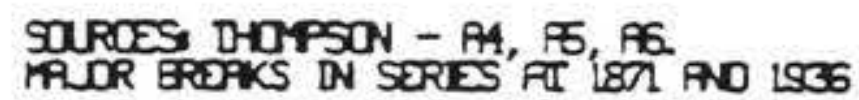


to all the series, which documents their definitions and construction, and provides them on a long term basis as has now been done for the work force. There have been a number of attempts - Brendan collected a lot of such series himself- but typically there has neither been the institutional basis nor the resource funding for what - as Brendan's effort has shown - can be a formidable amount of work. There is a research priority in bringing together the various historical series in a documented, consistent and readily accessible form.

\section{Appendix I: Brendan James George Thompson: A Brief Life}

1943 (22 July) born in Fielding.

1957-1961: St Andrews College, Christchurch.

1962-1968: University of Canterbury (MA in History, 1968).

1968-1970: New Zealand Broadcasting Corporation (Radio announcer in Rotorua, Wanganui, Napier).

1969: Married Carol (Fitzsimons)

1970-1972: University of Pennsylvania (MA in Economic History)

1972: Jolyon born.

1972-1973: BBC World Service (News reader, announcer, and current affairs interviewer in London)

1973-1974: Freelance Broadcaster, Wellington.

1975: Damon born.

1975-1976: Teacher, St George's School, Wanganui.

1976-1978: Victoria University of Wellington. Lecturer in Economic History (1976-1977), lecturer in economics (1978).

1979-1996: University of Waikato. Lecturer in economics (1979-1986), senior lecturer in economics (1986-1996)

1976: Visiting Fellow, University of Pennsylvania.

1996 (25 January) Died of cancer.

Source: 1994 Curriculum Vita of Brendan Thompson, plus family provided information.

\section{Appendix 2: Publications}

The following list of publications comes from a Curriculum Vitae compiled in 1994. The commentary is Brendan's. The list has been arranged into chronological order, to give an indication of the development of Brendan's thinking.

Publications on the work force and related statistical and economic issues

1977 "Checking up on the Census," Victoria University of Wellington Working Papers in Economic History, 77/5, August 1977.

1978 "A Comparison of Factory Production Statistics with the Census, 19361921," Victoria University of Wellington Working Papers in Economic History, 78/2, May 1978.

1978 "The Maori Work Force by Industry, 1926-1945," Victoria University Working Papers in Economic History, 78/4, November 1978.
1979 "Checking up on the Census," New Zealand Economic Papers, 13 (1979), p.140-157.

1979 "Social Mobility and Opportunity in Nineteenth Century New Zealand," comments on a paper prepared by Miles Fairburn for the Turnbull Social History Conference, August 1978, New Zealand Journal of History, 13:1 (April 1979), p.62-63.

1979 "The Relationship between Registered Unemployment and Census Unemployment," Labour and Employment Gazette, 29:4 (December 1979), p.16 (with A. Endres). Although brief, this pioneering article has become part of the literature on the topic. It has been cited in New Zealand Economic Papers, 14 (1980), p.106; New Zealand Population Review, 11:2 (July 1985), p.138 and 12:3 (October 1986), p.251; and Massey Economic Papers, 3:B8507 (October 1985), p. 185.

1980 "Employment Patterns among the Elderly," New Zealand Demographic Society, Proceedings of the Sixth Annual Conference, Wellington, 1980 (66 pages).

1980 "A Comparison of the Census and the Factory Production Statistics for New Zealand, 1936," University of Waikato Working Papers in Economics, no.2, 1980.

1981 “Job Stealers?" New Zealand Listener, 11 July 1981, p.62-63.

1985 "Industrial Structure of the Work Force," Economic and Social Commission for Asia and the Pacific, Population of New Zealand (I. Pool, ed.), 2 vols, Country Monograph Series, no.12, New York: United Nations, 1985, vol. 2, chapter 18, p.114-38. This is the first attempt to chart and account for the changes in the broad industrial structure of the New Zealand work force since 1839 on a reasonably consistent basis. It is currently the definitive reference in this field. It is also the first work to document and account for changes in the industrial structure of the Maori work force.

1986 "Labour Force," The Uses and Limitations of Census Data: Recent Censuses to 1981 (C. Crothers, ed.), Occasional Paper no.6, Wellington: New Zealand Demographic Society (Inc.), 1986.

1991 "New Zealand's Changing Industrial Structure in International Perspective," Proceedings of the Conference of the Sociological Association of Aotearoa, University of Waikato, 8 December 1991.

In addition the following paper, which does not seem to have been published, illustrates the further development of the work.

1992 Canada's Changing Industrial Structure in International Perspective: From Laggard to Leader, Paper presented at the 1992 conference of the 
Association of Canadian Studies in Australia and New Zealand, Victoria University of Wellington, 14-16 December, 1992.)

Finally the following paper should be added:

In preparation Industrial Structure of New Zealand Work Force (See Appendices III, IV, V.)

\section{Other Publications}

1967 “The Canterbury Farm Labourers' Dispute, 1907. 1908, 11 M.A. thesis, University of Canterbury, 1967. Although this has not been published, I have included it because it has become a standard reference in its field. It is described as "an excellent study" in J. Holt, Compulsory Arbitration in New Zealand: The First Forty Years, Auckland: Auckland University Press, 1986, p.91. It is also cited in E. Olssen, The Red Feds: Revolutionary Industrial Unionism and the New Zealand Federation of Labour 1908-14, Auckland: Oxford University Press, 1988 and in J. Tolerton, Ettie: A Life of Ettie Rout, Auckland: Penguin Books, 1992.

1973 "Ploughboys of the Plains Unite," New Zealand Listener, 22 December 1973, p.18. An example of the use of history to provide background for a current issue.

1976 Review of Bacon, Robert, and Eltis, Walter, Britain's Economic Problem: Too Few Producers, London: the Macmillan Press Ltd, 1976, New Zealand Economic Papers, 11, 1977, p.215-17.

1981 "Thinking both Big and Small - the Kiwi Compromise," National Business Review, 6 July 1981, p.7. An example of using history as a source of ideas for current policy making.

1982 "A Selective Index of the New Zealand Listener, 31 January 1981-18 April 1982," Hamilton: Department of Economics, University of Waikato, 1982.

1989 "Human Rights and History Teaching," New Zealand Historical Association Newsletter, 1989, no.4, p.2-14.

1992 "The Industrial Phase in Australia's Economic Development and its Effect on Australia's Place in the World," Pacific Basin Studies Review, 3:1 (1992), p.6-8. An example of using history to illuminate present day issues.

1993. "Getting the New Zealand Economy Growing," National Strategies for Australasian Countries (Leach, R., ed.), chapter 6, p.70-77, Brisbane:Queensland University of Technology, 1993. cific Basin Studies Review, 4:1 (1993), p.2-4. Source: 1994 Curriculum Vita of Brendan Thompson

\section{Appendix III: Contents of Industrial Structure of the New Zealand Work Force}

Chapter 1: Introduction (39 pages) appears fairly complete, but because it is an introduction there is not a lot of important content in it. A useful component is that at the end is a list of 18 hypotheses that were to be tested. They come from the international literature, giving a sense of where Brendan was going in New Zealand terms.

Chapter 2: The Work Force in New Zealand Censuses (13 pages) also appears fairly complete. It is mainly definitions.

Chapter 3: The Size of the Early New Zealand Work Force. 1769-1852 (40 pages, 14 tables) also appears fairly complete. The tables are working ones. The summary ones are in "Appendices". 14

Chapter 4: The Size of the New Zealand Work Force, 1858 1936 ( 64 pages, 21 tables) is not quite as complete because some of the tables are hand written, and they show reworking (which leaves open the possibility that the Brendan had not finished working on them). Again the summary tables are in Appendices. I am also puzzled about the balance of the chapter, which seems to be primarily about farm workers.

(It is possible that Brendan had in mind a further chapter on the manufacturing sector which either he never completed, or has not yet been found. This is hinted because there is an untitled chapter which appears to have been Chapter 5. ${ }^{15}$ )

Comparisons to Official Sources (144 pages, 64 tables) consists of a series of studies of various tertiary occupation sectors.

Appendices ( 112 pages, 43 tables, plus bibliography). This seems to be either summaries or working tables of Brendan's quantitative work. The first 27 pages are typed, and seem to cover chapter 3 . The remaining are (often not very good photocopies of) handwritten tables, probably covering the period from 1858 to 1936 . They may well be his copy of tables given to someone to type up. The tables are summarized in appendix $\mathrm{V}$.

\section{Appendix IV: Master Tables}

These "A tables" appear to be the summary tables of the work. Tables Al to A3 have not been located. More may have been intended, because there was also work on the employment status of the work force from 1891. The existing tables have a few hand revisions and gaps.

Commentary in italics.

Table A.4

Detailed Industrial Structure of the New Zealand Non-Maori Workforce, 1839 1871. Numbers and percentages. 1839 
$1843,1845,1848,1861,1864,1867,1871$. Farming, Mining, Secondary, Civilian Services, Soldiers.

Table A.5

Detailed Industrial Structure of the New Zealand Non-Maori Workforce, 18711936. Numbers. 1871, 1874, 1878, 1881, 1886, 1891, 1896, 1901, 1911, 1916, 1921, 1926, 1936. Farming, Hunting \& Fishing, Forestry, Mining, Manufacturing (for 1871, 1874), Factory Manufacturing, Handicraft, Building \& Construction, Rail transport, Other transport, Trade, Services.

Table A.6

Detailed Industrial Structure of the New Zealand Non-Maori Workforce, 18711936. Numbers. 1936, 1945, 1951, 1956, 1961, 1966, 1971, 1976, 1976 adjusted, 1981. Agricultural \& livestock production, Forestry fishing \& hunting, Mining, Manufacturing, Construction, Electricity gas water and sanitary services, Trade, Finance insurance \& real estate, Transport storage \& communication, Government, Community business \& recreational services, Personal services, Private domestic service (combined with personal service from 1951).

Table A.7 Detailed Industrial Structure of the New Zealand Non-Maori Workforce, 18711936. (Percentages - see Table A.5)

Table A.8 Detailed Industrial Structure of the New Zealand Non-Maori Workforce, 19361981. (Percentages - see Table A.6)

Table A.9 Detailed Industrial Structure of the New Zealand Non-Maori Male Workforce, 1874-1936. (Numbers - See Table A.5)

Table A.10 Detailed Industrial Structure of the New Zealand Male Workforce, 1936-1981. (Numbers - see Table A.6, except no 1976 although there is 1976 adjusted)

Table A.11 Detailed Industrial Structure of the New Zealand Non-Maori Male Workforce, 1871-1936. (Percentages -See Table A.9)

Table A.12 Detailed Industrial Structure of the New Zealand Male Workforce, 1871-1936. (Percentages - see Table A.10)

Table A.13

Detailed Industrial Structure of the New Zealand Non-Maori Female Workforce, 1871-1936. (Numbers - See Table A.5)

Table A.14 Detailed Industrial Structure of the New Zealand Female Workforce, 1936-1981. (Numbers - See Table A.10)
Table A.15 Detailed Industrial Structure of the New Zealand Non-Maori Female Workforce, 1871-1936. (Percentages - See Table A.13)

Table A.16 Detailed Industrial Structure of the New Zealand Female Workforce, 1936-1981 (Percentages - See Table A.14)

Table A.17 Industrial Structure of the Maori Workforce, 1926-1981. (Numbers - See Table A.6, but includes 1926, and Private domestic service for all years.)

Table A.18 Industrial Structure of the Maori Workforce, 1926-1981. (Numbers - See Table A.17)

Table A.19 Industrial Structure of the Maori Male Workforce, 1926-1981. (Numbers - See Table A.17)

Table A.20 Industrial Structure of the Maori Male Workforce, 1926-1981. (Percentages See Table A.19)

Table A.21 Industrial Structure of the Maori Female Workforce, 1926-1981. (Numbers - See Table A.17)

Table A.22 Industrial Structure of the Maori Female Workforce, 1926-1981. (Percentages . See Table A.20)

\section{Appendix V: Tables in Appendices}

page numbers.

TABLE A.1. 2-4.

Derivation of Estimated New Zealand Work Force, excluding Missionaries, December 1839.

TABLE A.1.2 5-6.

Derivation of Estimated New Zealand Work Force, 1843.

TABLE A.1.2.1 7-11.

Europeans Living Outside Settlements, Except Missionaries and Whalers, 1843.

Estimated Sex Distribution.

TABLE A.3.1 12-13.

Derivation of Estimated New Zealand Work Force, 1845.

TABLE A.3.1.1 14-15.

Europeans Living Outside Settlements, Except Missionaries and Whalers, 1845.

Estimated Sex Distribution.

TABLE A.4.1 16-17.

Derivation of Estimated New Zealand Work Force, 1848. 
TABLE A.4.1.1 18.

Europeans Living Outside Settlements, Except Missionaries and Whalers, 1848.

TABLE A.1.5 19-20.

Estimated New Zealand Work Force, 1851.

TABLE A.1.6 21.

Estimation of the New Zealand Work Force by Sex, 184351.

\section{TABLE A.1.6.1 22.}

Estimation of New Zealand Female Work Force 1843-51.

\section{TABLE A.1.7 23.}

Estimation of Male and Female Participation Rates, New Zealand, 1843-51.

\section{APPENDIX 2 24-27.}

Errors in Statistics of New Zealand for Crown Colony Period, 1840-52.

At this point the typed tables cease, and the remainder are hand written, not always to be easily read. There is no pagination. That provided here is one added by numbering the pages in the order they appear. The number has been put in pencil on the back of each page.

\section{TABLE A.1.8 28-29.}

Derivation of New Zealand Work Force 1858-71.

\section{TABLE A.1.8.1 30.}

Calculation of Soldiers' Families in New Zealand, 1858.

TABLE A.1.9 31.

Estimation of the new Zealand Work Force by Sex, 185871.

\section{TABLE A.1.9.1 32.}

Estimation of New Zealand Female Work Force, 1858, 1861.

\section{TABLE A.1.9.2 33.}

Proportion of Females in Occupations Containing Them, 1864.

\section{TABLE A.1.9.3 34.}

New Zealand Female Work Force, 1867, 1871.

TABLE A.1.10 35

Male and Female Participation Rates, New Zealand, 185871.

\section{TABLE A.1.11 36-37.}

Derivation of New Zealand Non-Maori Work Force, 1874, 1878.

\section{TABLE A.1.12 38-39.}

Derivation of New Zealand Non-Maori Work Force, 1881, 1886.
TABLE A.1.13 40-42.

Derivation of new Zealand Non-Maori Work Force by Employment Status, 1891.

TABLE A.1.13.1 43-49.

Transfers from Relative Assisting but not Receiving Wages and Other Undescribed, 1891-1911.

TABLE A.1.13.2 50-53.

Allocation of Males in Certain Occupations Transferred from Relatives Assisting but not Receiving Wages and Others Undescribed, 1891.

\section{TABLE A.1.13.3 54-55.}

Estimated Withdrawals from Relative Assisting but not Receiving Wages and Other Undescribed, 1891.

\section{TABLE A.1.13.4 56-60.}

Estimated Unemployed Wage Earners Transferred from Relative Assisting but not Receiving Wages and Other Undescribed, 1891.

\section{TABLE A.1.13.6 ${ }^{16} 61-64$.}

Female Farmers Classified as Relatives Assisting and Others Undescribed, 1891-1916.

\section{TABLE A.1.14 65-67.}

Derivation of New Zealand Non-Maori Work Force by Employment Status, 1896.

\section{TABLE A.1.14.1 68.}

Withdrawals from Relative Assisting but not Receiving Wages and Other Undescribed, 1896-1911.

\section{TABLE A.1.15 69-71.}

Derivation of New Zealand Non-Maori Work Force by Employment Status, 1901.

\section{TABLE A.1.16 72-74.}

Derivation of New Zealand Non-Maori Work Force by Employment Status, 1906.

\section{TABLE A.1.17 75-77.}

Derivation of New Zealand Non-Maori Work Force by Employment Status, 1911.

TABLE A.1.18 78-80.

Derivation of New Zealand Non-Maori Work Force by Employment Status, 1916.

TABLE A.1.19 81-83.

Derivation of New Zealand Non-Maori Work Force by Employment Status, 1921.

TABLE A.1.20 84-86.

Derivation of New Zealand Non-Maori Work Force by Employment Status, 1926.

TABLE A.1.21 87-89.

Derivation of New Zealand Non-Maori Work Force by Employment Status, 1936. 
TABLE A.1.22 90.

Derivation of New Zealand Work Force, 1926.

TABLE A.1.23 91.

Derivation of New Zealand Work Force, 1936.

TABLE A.1.24 92 .

Derivation of New Zealand Work Force, 1945.

TABLE A.4 93-96.

Transfers from Not Applicable, 1916.

TABLE A.4.1 97-100.

Categories with Considerable Agreement.

TABLE A.4.3 101-105.

Categories with Inadequate Official Figures.

TABLE A.4.7 106-108.

Categories with No Official Figures for Employees

\section{Acknowledgements}

I am grateful to assistance of Carol Thompson in the preparation of this work, and of the Thompson family, Carol, Damon and Jolyon, for their giving me access to Brendan's papers. His Department of Economics at the University of Waikato has also been supportive.

\section{Notes}

1. The omission is quoted below.

2. See G.R. Hawke, 1979, Disaggregation of the New Zealand Labour Force, 1871-1936, VUW Working Papers in Economic History, 79/1, Victoria University of Wellington Economics Department, January 1979.

3. The text uses "labor force" because it was for a US audience. Brendan may have used "work force" (sometimes "workforce") to avoid this distinction.

4. It seems likely that the missing tables include estimates by gender between 1843 and 1871 , as estimates appear in the appendix tables. However the work force aggregate in the appendix tables, differ from the figures in the A tables.

5. Requests for access to Brendan's papers should be made to Carol Thompson, 104 Hillcrest Road, Hamilton.

6. Output per worker is not the same thing as labour productivity (or output per employed worker) although in the long run they should have similar trends.

7. K. Rankin (1992) “New Zealand's Gross National Product: 1859-1939" Review of Income and Wealth, Series 38, Number 1, March 1992, p.49-69.

8. B.T. Lineham (1968) "New Zealand's Gross Domestic Product 1918/38", New Zealand Economic Papers, Vol 2, No 2.
9. B.H. Easton (1990) A GDP Deflator Series for New Zealand: 1913/4-1976/7, Massey Economic Papers B9004, December 1990, p.101. A revised version of the series is in B.H. Easton (forthcoming) In Stormy Seas: The Post-War New Zealand Economy, Otago University Press, Dunedin.

10. Now published as B.H. Easton, Towards a Political Economy of New Zealand,(1994 Hocken Lecture), Hocken Library. University of Otago, Dunedin, 1996.

11. Non-Maori to 1921, Maori and Non-Maori thereafter.

12. At the level of aggregation of the Thompson A tables, the quarrying activities of whaling and sealing are not separated out from "Other", even though they were very important before 1860 .

13. Includes the building and construction, and the electricity, gas, and water sectors. The combination is a consequence of the sectors being combined before 1871 .

14. The split between Chapters 3 and 4 reflects that from 1858 the data is based on Censuses.

15. There are various indications in the tables of Chapter 4 , that originally they were intended to be in a Chapter 3 .

16. There appears to be no TABLE A.1.13.5.

\section{Author}

Brian Easton holds positions at the University of Auckland. the Central Institute of Technology, Massey University, Victoria University of Wellington and the Wellington School of Medicine of the University of Otago. 